http://jmscr.igmpublication.org/home/ ISSN (e)-2347-176x ISSN (p) 2455-0450

crossref DOI: https://dx.doi.org/10.18535/jmscr/v9i10.06

Journal Of Medical Science And Clinical Research

\title{
Levels of AMH in Main Phenotypes of PCOS and its role in predicting severity of PCOS
}

\author{
Authors \\ Dr Meenakshi Rana ${ }^{1}$, Dr Kamini Randhawa ${ }^{2 *}$ \\ ${ }^{1}$ Junior Resident, Department of Obstetrics and Gynaecology, IGMC Shimla \\ ${ }^{2}$ Junior Resident, Department of Anesthesiology, IGMC Shimla \\ "Corresponding Author \\ Dr Kamini Randhawa \\ Junior Resident, Department of Anesthesiology, IGMC Shimla
}

\begin{abstract}
Background: The ultimate pathogenesis of polycystic ovary syndrome is not well known but the failure of follicular maturation leading to accumulation of preantral and small antral follicles and anovulation, both of these significantly contribute to production and increased levels of AMH.

Objectives: To characterize the difference in circulating anti mullerian hormone level between main phenotypic groups and evaluate the role of AMH in predicting the severity of PCOS.

Design: Prospective observational study

Setting: Department of Obstetrics and Gynecology, KNHSH IGMC Shimla.

Subjects: 200 women of age group 15-35 yearwith complaints of menstrual irregularities or symptoms of hyperendrogenism fulfilling the inclusion and exclusion criteria were included.

Methods: Serum levels of FSH, LH, Prolactin, TSH, FBS and AMH were measured on $2^{\text {nd }}$ day of natural cycle. For qualitative variables frequency/percentage was calculated and for quantitative variables mean/ standard deviation was calculated and compared.

Results: The mean serum AMH levels were $8.3+\ldots 3.63 \mathrm{ng} / \mathrm{mL}$ in Group 1, 8.02+_4.2 $\mathrm{ng} / \mathrm{mL}$ in Group 2, $7.89+4.4 \mathrm{ng} / \mathrm{mL}$ in Group 3, and $6.1+2.4 \mathrm{ng} / \mathrm{mL}$ in Group 4. The highest levels of AMH were found in Group 1. All other parameters were comparable among all four group.
\end{abstract}

\section{Introduction}

Polycystic ovarian syndrome characterised by hyperendrogenism and ovulatory dysfunction and is the most frequent cause of anovulatory infertility and hyperandrogenism in young women. It is one of most common gynecologic endocrine abnormality affecting $6.6-8 \%$ of women of reproductive age group. AMH is also known as mullerian inhibiting substance, has a glycoprotein dimer structure and is a member of the transforming growth factor B super family. Levels of $\mathrm{AMH}$ are closely correlated with the number of early antral follicles in both healthy women and women with PCOS. Several studies also suggest that serum levels of AMH may be a marker for polycystic ovary syndrome. In female until puberty serum levels of AMH are negligible, but they increase thereafter to the levels comparable to those in men due to follicular growth. Thus it's serum concentration in females 
are thought to reflect the size of ovarian follicle pool. Thus Impaired folliculogenesis may result in excess accumulation of preantral and small antral follicles which may ultimately cause increased AMH levels associated with PCOS. AMH has been recommended as a diagnostic marker for PCOS in recent years. In this study we assessed the levels of $\mathrm{AMH}$ in different phenotypes of PCOS.

\section{Material and Methods}

This prospective observational study was conducted in the department of Obstetrics and gynaecology at Kamla Nehru State Hospital for Mother and Child IGMC Shimla from 1st July 2018 to 30th June 2019. After taking an informed consent a total of 200 women were prospectively enrolled in this study. The inclusion criteria were women with age between 15-35 yr , having both ovaries, with history of menstrual irregularities , history of hyperandrogenism. Woman with thyroid diseases, hyperprolactinemia, diabetes mellitus, on hormonal therapy and with history of previous surgery on ovaries were excluded from the study.

After taking informed consent from all the women detailed history was taken followed by general physical and systemic examination. On day 2 of menstrual cycle a rouitne gynecological examination performed followed by ultrasonography and individual pateint was assigned to a group according to the presence of the symptoms. Then AMH levels of the patients done on Day2 of menstrual cycle. Statistical analysis was done using SPSS. Data was entered into SPSS and analysed. For qualitative variables frequency/percentage was calculated and for quantitative variables mean/ standard deviation was calculated.

\section{Results}

Of the 200 subjects enrolled in this study, 90 (45\% patients were in group 1 ( $\mathrm{PCOM}+\mathrm{OA}+\mathrm{HA})$, $52(26 \%)$ patients were in group 2 (PCOM+OA), $30(15 \%$ patients were in group $3(\mathrm{OA}+\mathrm{HA})$, and $28(14 \%)$ patients were in group 4 ( OA +PCOM). The data of four groups shown in Table 1. All the four groups were comparable in terms of age, BMI and socioeconomic status. The mean serum AMH levels were $8.3+\ldots 3.63 \mathrm{ng} / \mathrm{mL}$ in Group 1, $8.02+\_4.2 \mathrm{ng} / \mathrm{mL}$ in Group 2, 7.89+_4.4 ng/mL in Group 3, and 6.1+_2.4 ng/mL in Group 4. The highest levels of AMH were found in Group 1. Fig. 1 presents the mean serum AMH levels of the four groups based on PCOS-related phenotypes. Women with $\mathrm{PCOM}+\mathrm{OA}+\mathrm{HA}$ (Group 1) had higher serum AMH levels than those with $\mathrm{PCOM}+\mathrm{OA}($ Group 2), but the difference was not statistically significant.

There were no statistically significant differences among the four groups in terms of FSH, LH, Prolactin, TSH and FBS levels. Table 2 presents the mean serum levels of FSH, LH, Prolactin, TSH, and FBS in four group's bsed on PCOS related phenotypes.

\section{Table 1}

\begin{tabular}{|c|c|}
\hline & $\begin{array}{c}\text { Mean AMH level } \\
(\mathbf{n g} / \mathbf{m l})\end{array}$ \\
\hline $\begin{array}{c}\text { Group 1 } \\
(\mathrm{n}=90)\end{array}$ & $8.3+\_3.63$ \\
\hline $\begin{array}{c}\text { Group 2 } \\
(\mathrm{n}=52)\end{array}$ & $8.02+\_4.2$ \\
\hline $\begin{array}{c}\text { Group 3 } \\
(\mathrm{n}=30)\end{array}$ & $7.89+\ldots 4.4$ \\
\hline $\begin{array}{c}\text { Group 4 } \\
(\mathrm{n}=28)\end{array}$ & $6.1+\ldots 2.4$ \\
\hline
\end{tabular}


Table 2

\begin{tabular}{|c|c|c|c|c|c|}
\hline & $\begin{array}{c}\text { FSH } \\
(\mathrm{IU} / \mathrm{ml})\end{array}$ & $\begin{array}{c}\text { LH } \\
(\mathrm{IU} / \mathrm{ml})\end{array}$ & $\begin{array}{c}\text { Prolactin } \\
(\mathrm{ng} / \mathrm{ml})\end{array}$ & $\begin{array}{c}\text { TSH } \\
(\mathrm{mIU} / \mathrm{L})\end{array}$ & $\begin{array}{c}\text { FBS } \\
(\mathrm{mg} / \mathrm{dl})\end{array}$ \\
\hline $\begin{array}{c}\text { Group 1 } \\
(\mathrm{n}=90)\end{array}$ & 5.38 & 5.89 & 12.2 & 2.13 & 91.6 \\
\hline $\begin{array}{c}\text { Group 2 } \\
(\mathrm{n}=52)\end{array}$ & 5.53 & 6.16 & 11.45 & 2.06 & 91.0 \\
\hline $\begin{array}{c}\text { Group 3 } \\
(\mathrm{n}=30)\end{array}$ & 5.55 & 6.12 & 11.36 & 2.08 & 92.5 \\
\hline $\begin{array}{c}\text { Group 4 } \\
(\mathrm{n}=28)\end{array}$ & 5.87 & 5.76 & 11.89 & 2.19 & 95.4 \\
\hline
\end{tabular}

\section{Discussion}

In our study, AMH levels were compared among four main PCOS phenotypes which were devided using the three main accepted criteria that is PCOM, OA, and HA. Various studies have shown that in women with PCOS had high levels of AMH as compared with non PCOS women. Our study showed high circulating AMH levels in Group 1 in which all three criteria were there. These results indicate that PCOM is the most effective factor influencing AMH levels. Lin et al. divided all patients into three groups: high $\mathrm{AMH}$ (>11 ng/mL), moderate AMH (4-11 ng/mL), and low AMH $(<4 \mathrm{ng} / \mathrm{mL})$. Our study suggest that $\mathrm{OA}$ also affect AMH levels in patients with PCOS. AMH serum levels correlated well with parameters such as oligo/anovulatory periods which are indicative of the extent of ovarian dysfunction. As shown in Table 1, there was only a slight difference in AMH levels between groups 1 and 2 and there was difference between AMH levels in group 1 and group 3. Hyperandrogenic (Group 1) PCOS patients have AMH concentrations statistically different to those of nonhyperandrogenic (Group 4). Piouka et al. reported that $\mathrm{AMH}$ levels were higher in anovulatory and hyperandrogenic women with NIH-defined "classical" PCOS without PCOM as compared with both ovulatory women with PCOM and HA and anovulatory women with PCOM but normal androgen levels. In contrast to their results, we showed that serum AMH concentrations were positively influenced by PCO morphology. Similarly, they found the highest serum AMH levels in the $\mathrm{PCOM}+/ \mathrm{OA}+/ \mathrm{HA}+$ group. Our results show that $\mathrm{HA}$ is the least effective factor influencing serum AMH levels. Also OA is the more reliable criterion than $\mathrm{HA}$ for increased AMH levels. The most important criterion affecting serum AMH levels is PCOM, followed by OA. The highest AMH level was associated with the three main diagnostic criteria. If we divide our results into percentiles according to AMH levels (Table 2), the AMH value increases in proportion to the increase in the severity of PCOS. The highest AMH levels were found in Group 1On the other hand, the lowest level of $\mathrm{AMH}$ was found in Group 4 (OA+ PCOM).

\section{Conclusion}

In conclusion, our prospective study showed that the levels of AMH were highest when associated with the presence of the all three parameters. AMH levels correlate best with PCOM and AMH levels highly correlated with follicles number. In addition, OA contributes to increased $\mathrm{AMH}$ levels. HA criteria were found to have less influence on $\mathrm{AMH}$ levels. AMH levels seem to have a diagnostic role in determining the severity of PCOS, also much more data and further studies are required to evaluate its diagnostic role in PCOS.

\section{References}

1. Sahmay S, Cetin M, Ocal P, et al. Serum anti-Mu“ llerian hormone level as a predictor of poor ovarian response in in vitro fertilization patients. Reprod Med Biol 2011;10:9-14.

2. Ocal P, Sahmay S, Cetin M, et al. Serum anti-Mu“ llerian hormone and antral follicle count as predictive markers of 
OHSS in ART cycles. J Assist Reprod Genet 2011;28:1197-203.

3. Weghofer A, Kim A, Barad DH, et al. Follicle stimulating hormone and anti$\mathrm{Mu}$ “ llerian hormone per oocyte in predicting in vitro fertilization pregnancy in high responders: a cohort study. PLoS One 2012; 7:e34290.

4. Cate RL, Mattaliano RJ, Hession C, et al. Isolation of the bovine and human genes for $\mathrm{Mu}$ “ llerian inhibiting substance and expression of the human gene in animal cells. Cell 1986;45:685-98.

5. Salmon NA, Handyside AH, Joyce IM. Oocyte regulation of anti-Mu“ llerian hormone expression in granulosa cells during ovarian follicle development in mice. Dev Biol 2004;266:201-8.

6. de Vet A, Laven JS, de Jong FH, et al. Anti-Mu“ llerian hormone serum levels: a putative marker for ovarian aging. Fertil Steril 2002;77:357-62.

7. Lie Fong S, Visser JA, Welt CK, et al. Serum anti-Mullerian hormone levels in healthy females: a nomogram ranging from infancy to adulthood. J Clin Endocrinol Metab 2012;97:4650-5.

8. Rotterdam ESHRE/ASRM-sponsored PCOS Consensus Workshop Group Revised 2003 consensus on diagnostic criteria and long-term health risks related to polycystic ovary syndrome (PCOS). Hum Reprod 2004; 19:41-47.

9. Siow Y, Kives S, Hertweck P, et al. Serum Mü llerian-inhibiting substance levels in adolescent girls with normal menstrual cycles or with polycystic ovary syndrome. Fertil Steril 2005;84:938-44.
10. Hart R, Doherty DA, Norman RJ, et al. Serum anti-Mu“ llerian hormone (AMH) levels are elevated in adolescent girls with polycystic ovaries and the polycystic ovarian syndrome (PCOS). Fertil Steril 2010;94:1118-21.

11. Jonard S, Robert Y, Cortet-Rudelli C, et al. Ultrasound examination of polycystic ovaries: is it worth counting the follicles? Hum Reprod 2003;18:598-603.

12. Lin $\mathrm{YH}$, Chiu WC, Wu CH, et al. Anti$\mathrm{Mu}$ " llerian hormone and polycystic ovary syndrome. Fertil Streil 2011;96:230-5. 